\title{
A Critical Appraisal of Zakir Naik's Islamic Evangelism
}

\author{
MAZIAH MUSTAPHA* \& MOHD ABBAS ABDUL RAZAK¹
}

\begin{abstract}
Though Islam is a religion against compulsion in inviting others into its fold, but it allows to a certain degree for Muslim scholars to engage in any form of peaceful, ethical and intellectual debate/discourse with people of other faith. Ever since this message was communicated through the Qur'an, there appeared in the Muslim world many intellectuals who engaged people of other faith in discussing issues related to God and spirituality. While the Muslim world still celebrates the contribution of past renowned Muslim scholars in the area of comparative religion, this small-scale research is designed to investigate the approaches, contributions and controversies that surround Naik who is a contemporary Muslim scholar of comparative religion. Even though many recognize his intellectual competency in discussing other religions, but there are people around the globe who find his public lecture provocative, cynical and disparaging towards other religions. Through this qualitative study the researchers intend to conduct a critical appraisal on Naik's religious propagation. Besides that, the researchers will also analyze some of the criticisms hurled at him. The critical analysis of the research will objectively discuss Naik's method of preaching, personality, style of public lecture, etc. The textual-analysis method will be employed to interpret the pertinent data of this research that come in the form of Naik's public lectures and written documents.
\end{abstract}

Keywords: da'wah, interfaith dialogue, Islamic evangelism, Zakir Naik

In recent times, Naik's rise to popularity in the area of comparative religion has caused a controversy and consternation in some quarters of non-Muslims in the world. The accusation on Naik goes from disparaging other people's faith, to be associated with Muslim terror organizations. The latter accusation implicates Naik of either approving terrorism or supporting it clandestinely. In the wake of these latest accusations, this paper intends to investigate critically Naik's method of communicating religious ideas. Very precisely, this research will analyze his personality, body language, content of speech and approach in sharing his knowledge and understanding of other religious scriptures with their adherents. As a prelude to the crux to this research, will be a review of literature on works, dialogues and debates held by early and contemporary Muslim scholars with other faith groups. Upon conducting a critical appraisal the researchers will put forward some recommendations.

1 Maziah Mustapha*(corresponding author), Ph.D., assist. prof. at the Department of Usul al-Din and Comparative Religion, Kulliyyah of Islamic Revealed Knowledge and Human Sciences, International Islamic University Malaysia (IIUM), 53100 KUALA LUMPUR, Malaysia, email: mazmustapha@iium.edu.my; Mohd Abbas Abdul Razak, Ph.D., assist. prof. at the Department of Fundamental \& Interdisciplinary Studies, Kulliyyah of Islamic Revealed Knowledge and Human Sciences, International Islamic University Malaysia (IIUM), 53100 KUALA LUMPUR, Malaysia, email: maarji@iium.edu.my. 


\section{Literature Review}

In the course of history, Islamic civilization has come in contact with a number of other civilizations, Greek, Roman, Persian, and Indian to name a few. Meeting people of other civilizations has inspired Muslim scholars to study keenly of their religions and system of beliefs. After learning other religions Muslim scholars held meaningful dialogues with the adherents of those religions. Among the many religions of the world, Judaism and Christianity became the main interest of the Muslim scholars for the reason; they are very close to their own faith.

Muslims who follow the divine revelation revealed to Prophet Muhammad (PBUH) observe a tolerant attitude towards people of other religions. The philosophy of coexistence preached by the Qur'an became the golden means by which Muslims were able to live peacefully with people of other faith. Truly, peace is the central core of the Islamic teaching explained in the Qur'an and Sunnah. It is this message of peace that prevailed the Islamic Civilization over all other human civilizations of the world. Early Muslim scholars had demonstrated well this aspect of the Qur'anic teaching in their intellectual discourse. It has been reported that during the early period of the Islamic civilization, many cordial religious debates have taken place between Muslim scholars and others at an intellectual level. Muslim scholars maintained their best behavior during their intellectual discourse with others as they were told in the Qur'an, (Al-Qur'an 16:12, 56:108) Generally, for centuries, except for a few isolated cases, interfaith dialogues went on peacefully and intellectually between Muslims and others in many empires of the Muslims. Tension and confrontation only happened when Muslim or non-Muslim scholars failed to observed the maxim of 'agree to disagree'. What follows below is a review on works of Muslim scholars engaged in interfaith dialogues and literary works.

Maulana M. Rahmatullah Kairanvi (1818-1891), who was a reputed Mufti and Sunni Shariah scholar, was also equally competent as a scholar of comparative religion. He was well-known for his Magnus opus the 'Izhar ul-Haqq' (The Truth Revealed). First published 1864, this book argues intellectually on the validity and authenticity of the Bible. This book was written during the British rule of India to defend Islam and its pristine teachings. Very particularly, it was as a response to Rev. C. C. P. Fonder's book in Urdu 'Meezanul Haq'. Driven by his passion for Christian missionary work, Fonder made slanderous statement against Islam with the intention of creating confusion in the Muslim minds. In giving her comments on Izhar ul-Haqq, German expert on Islamic Studies, Christine Schirrmacher (1962-) said the following:

"The Demonstration of the Truth' (Izhar al-haqq) served as a summary of all possible charges against Christianity and was therefore used after al-Kairanawi's death as a sort of encyclopedia since al-Kairanawi extended the material of former polemicists like 'Ali Tabari, Ibn Hazm or Ibn Taymiyya to a great extent." (Schirrmacher 1997).

In a way, Kairanvi's monumental work was a response to the Christian offensive attack on Islam in British India. Through his research, he lucidly argued that the Bible is not authentic for the many contradictory statements found in it. Through this encyclopedic work, Kairanvi refuted the alleged doctrine on trinity believed by many Christians by giving many evidences from the Bible itself. At the same time, he proved the authenticity of the Qur'an and the prophethood of Muhammad (PBUH).

Coming in contact with the six volumes of Izhar ul-Haqq changed the life of Ahmad Hoosen Deedat (1918-2005) who was and still a celebrated scholar of comparative religion in the Muslim world, even after his death. Born and raised in South Africa, Deedat came under severe vilification of his religion and Prophet Muhammad (PBUH) by Christian missionaries at his workplace. Upon 
coming across Kairanvi's Izhar ul-Haqq, Deedat got a mastery over the book and further indulged himself in doing further research on comparative religion, particularly on Islam, Christianity and Judaism. Deedat shared his research findings in seminars, symposiums, workshops, public lectures, etc. The following are some of his books and pamphlets (Ahmad \& Idrees 2015):

1. Al-Qur'an - The Miracle of Miracles.

2. Arabs and Israel - Conflict or Conciliation?

3. Can You Stomach the Best of Rushdie?

4. Christ (PBUH) In Islam.

5. Crucifixion or 'Crucifiction'?

6. Is The Bible God's Word?

7. Muhammad (PBUH) - The Natural Successor to Christ (PBUH).

8. Resurrection or Resuscitation?

9. The God That Never Was.

10. Was Jesus Crucified?

11. What Is His Name?

12. What The Bible Says About Muhammad (PBUH)?

13. What Was The Sign of Jonah?

14. Who Moved The Stone?

15. The Choice (Part $1 \& 2$ )

16. Muhammad (PBUH) - The Greatest.

17. Islam's Answer to The Racial Problem.

18. The Muslim at Prayer.

19. "His Holiness" Plays Hide and Seek with Muslims.

20. Way to The Qur'an.

21. "Salaah" - The Muslim Prayer.

22. "50,000 Errors in the Bible?"

At times, Deedat also went on a lecture tour to many parts of the world. As a response to Pope John Paul II's call for mutual understanding, dialogue and respect between Islam and Christianity, in 1984, Deedat called for a debate to be held at the Vatican between the Pope and him. (Catholic News Service 2005) Unfortunately, the Pope did not respond to this call of Deedat. As recognition of his great contribution to Islamic propagation, the government of Saudi Arabia honored him with the King Faisal Award in 1986. Deedat in spite of having great number of admirers all over the Muslim world, still some people find his way of preaching a little bit harsh and belittling other people's faith. His sometimes harsh and impatient way of replying during debates and question and answer sessions is the reflection of the social and political milieus of South Africa in which he grew up. Deedat received criticism from Muslims as well as Non-Muslims. Liberal Muslim group in South Africa, which felt he inaccurately represented Islam and was intolerant towards the people of other religions. The Muslim Digest of South Africa devoted to criticize Deedat's stance and "his various dangerous activities". Deedat had been compared to the fundamentalists such as Rabbi Meir Kahane and Jerry Falwell (Esack 2002).

In stark contrast to Deedat is Yusuf Islam another present-day well-known preacher of Islam. Born as a Christian by the name of Steven Demetre Georgiou on 21st July, 1948. Later in his professional life he was known to his fans as Cat Steven. Prior to his conversion, Yusuf was a singer, songwriter and musician. Upon conversion to Islam in 1977, he began to respond too many of the controversial issues with regard to Islam and Muslims rose by non-Muslims, particularly those in the 
West. As a staunch Muslim, Yusuf threw his moral support behind the teaching of the holy script of the Muslims which is anchored on the Oneness of God, co-existence of civilizations, righteousness, charity, etc. Moreover, he was in the forefront for the cause of humanity, charity, world peace, development of education in the Muslim world, etc. His Islamic school and aid foundation, which he pioneered, is doing well to these days. He has a positive insight on the power of music, which he capitalized in his Islamic propagation. This move was well received by his Muslim and non-Muslim fans. With regard to music as an instrument to communicate his peace message, he said:

"There is a great deal of ignorance in the world about Islam today, and we hope to communicate with the help of something more refined than lectures and talks. Our recordings are particularly appealing to the young, having used songs as well as Qur'an verses with pleasing sound effects" (Hidayathullah 2001).

Yusuf's creative approach to Islamic propagation was never seen as a threat to many nonMuslims. This approach of Yusuf has brought him many invitations to be interviewed, to deliver public lecture, to join interfaith dialogue on radio and TV programs. In print too Yusuf has communicated, his message of peace and the beauty of Islam by authoring the following books:

1. The Story of Adam and the Creation.

2. A Talk on the Wild Side.

3. The Life of the Prophet.

4. Prayers of the Last Prophet.

5. Joseph's Surrender.

6. The Life and Times of Cat Steven.

7. My Journey from Cat Steven to Yusuf Islam.

8. In Search of the Centre of the Universe (Goodreads 2018).

The preceding was a brief literature review on Muslim scholarship on Comparative Religion. The review has highlighted some Muslim scholars preach their religion in an aggressive manner, while others take a more persuasive and diplomatic approach. What follows below here is an analysis on Naik's approach in communicating the message of Islam via public debate, print and electronic media.

\section{Biography and Achievement}

Little is known to the public on Naik's personal life as he has not written on it. His full name is Zakir Naik Abdul Karim Naik. He was born in Dongri, a predominantly Muslim locality in Mumbai, Maharashtra, India on the 18th October 1965, into a family of doctors. Naik got married and settled down in Mumbai. He married to Farhat Naik who shares similar interest in life. Farhat Naik also took a substantial position in the Islamic Research Foundation (IRF), a non-profit organization founded by her spouse. Naik's educational background is not in the area of Islamic studies. He went through a science based curriculum right from the very beginning of his educational endeavor. He was once a student at St. Peter's High School in Mumbai before he attended the Kishinchand Chellaram College in Churchgate. He followed his family tradition and opted to study medicine at Topiwala National Medical College and BYL Nair Charitable hospital, and later obtained a degree in Bachelor of Medicine and Surgery (MBBS) from University of Mumbai (A. Badaruddin 2016). 
Though completed his degree and was a practicing doctor in the beginning, he somehow lost the passion in his profession. His life took a turning when he met Ahmad Hoosen Deedat in 1987, which had inspired him in many ways. From that point of time he decided to be religious preacher in the area of Comparative Religion. Literally in 1991, he began his da'wah activities proselytizing the message of Islam. He founded the Islamic Research Foundation (IRF), a non-profit organization as a platform to disseminate his Islamic message. However, his career as a preacher started at a time when India was witnessing a rise in far-right Hindu groups. In 1992, the medieval-era Babri mosque in the city of Ayodhya was demolished to make way for a temple to be built in its place. Mumbai was ravaged by religious riots in the aftermath of the Babri mosque's demolition in 1990s. Naik occupied the leadership vacuum and turned into a hero for young Muslim youth in India. In BBC online news, he has been described in the following words:

"Zakir Naik has made himself into a brand. He is a package. His image is that of a man who is western-educated, with a medical background and wearing suit and tie. He has also cultivated the image of a man of Islam. He sports a beard and wears a skull cap" (BBC News 2016).

Naik's fame to be a reputed Muslim scholar of religion began after he went through a vigorous training program conducted by the late Ahmad Deedat, who was at that time a celebrated preacher and a scholar of comparative religion (Musthafa 2014). After getting the endorsement as a qualified scholar of comparative from his mentor, Naik started his propagation works by going on lecture tours to many parts of the world. His fluency in English, power of memory and mastery over many religious scriptures give him the confidence to engage spiritual leaders of other faith in discussing the concept of God, authenticity of their holy books and many other contemporary topics; like terrorism and extremism. It is an undeniable fact that Naik's scholarly presentation and analytical reasoning have attracted many from other faith groups to embrace Islam. In witnessing his participation in religious debates and his contribution to the cause of Islam, many in the Muslim world glorify him as their religious 'hero'. Besides his fan group, there are some within the Muslim community who disagree with his approach in dealing with the non-Muslims in any given debate. Many non-Muslim religious organizations and academics also raise criticism against Naik in his use of provocative statements and cynicism against other religious scriptures and catechisms. These non-Muslims and organizations claim that Naik's work is none other than one that disparages the doctrines of other faith groups. Below are some of Naik's books on comparative religion:

1. Answers to Non-Muslims' Common Questions about Islam.

2. Qur'an and Modern Science - Compatible or Incompatible?

3. Concept of God in Major Religions.

4. Christ (PBUH) In Islam.

5. Islam and Terrorism.

6. Similarities between Hinduism and Islam.

7. Answers to Common Questions about Islam By Non-Muslims

8. Who Have Some Knowledge about Islam.

9. Women's Rights in Islam- Protected or Subjugated?

10. Al Qur'an - Should it be Read with Understanding?

11. Is The Qur'an God's Word? (Goodreads 2018). 
Naik received lots of acknowledgment from state authorities to individual prominent Muslim scholars for his more than twenty-five years contribution in the area of Islamic propagation. His public lecture, compilation of writing and engagement in debates impressed many people of different countries, including, the West, South Africa, Middle East, the Indian Sub-continent, Asia and China. In the years between 2009 and 2015, Naik has been ranked in 'The 100 Most Powerful Indians list published by Indian Express', the 'Top 10 Spiritual Gurus of India' and 'the top 70 list of the '500 Most Influential Muslims in the World' for his crowd pulling public lectures and the popularity he enjoyed as a dynamic personality in the Muslim world. Constantly, from the year 2000 to 2015, Naik has been presented with many awards by the state authority for his achievement and contribution in the fields of Da'wah, Comparative Religion, Islamic Personality, for his outstanding service to Islam, Education and Philanthropy, significant service and contribution to the development of Islam and voluntary service for the cause of Islam at the international level. The greatest of his intellectual achievement came when Naik was presented with an Honorary Doctorate 'Doctor of Humane Letters' (Honoris Causa) by the Vice Chancellor of the University of The Gambia for his outstanding contribution and dissemination of knowledge in promoting research and delivery of community services internationally (King Faisal Prize 2015).

Like the popularity he enjoyed during mess lectures, Naik is also a popular figure online. He is the highest amongst the Muslim English Speakers who received more than 8 million likes on his Facebook Page. YouTube Vice President, Tom Pickett, certified Naik as 'awesome' for his 'likes' and 'popularity' on YouTube. His Peace TV Network also received good response ever since it was launched in January 2006 till October 2015. His TV programs broadcast in English, Urdu, Bangla and Chinese turned out to be the largest watched religious program in the world (Sadouni 2013).

\section{Criticism on Naik}

Besides the many compliments received by Naik for his great contribution in the field of Islamic propagation, he also received equal amount of criticism. Analysis proves that Muslim criticism against Naik mainly questions as to what extent his Islamic message and way of propagation are in line with mainstream Islam.

\section{Influence of Salafi}

In their observation, they see Naik as someone who promotes the 'Salafi' approach, an ultraconservative Islamic reformist movement in disseminating the Islamic message, which is harsh, dogmatic and domineering (Swami 2011).

Moreover, the recognition as a celebrated scholar who receives monetary funding and for having special relationship with the Saudi Government rightly befits Naik as a "Salafi scholar" to many of his opponents among the Muslims in India. When questioned during public forums, Naik neither publicly admitted nor denied that he is a "Salafi". Another possible reason as to why his opponents accuse him as being a "Salafi" scholar is due to his rigid and uncompromising stand towards the opinions of others; be they Muslim or Non-Muslim. The critics again argue the fact that Naik's strong stand on implementing the Islamic Law (Shari'a) on Muslims and Non-Muslims well justifies of his position as a "Salafi". As for Naik, he believes the Islamic law is the most practical and greatest module that can be used by the Muslims or Islamic countries only, but by the whole of humankind regardless of their religion. Naik's stand on the implementation of Shari'ah laws on Muslims and non-Muslims alike is seen as something quite not acceptable to his Muslim critics. Though they see the necessity to implement the Islamic laws as a prerequisite to establish an Islamic state goes in tandem with the objectives of the Shari'a (Maqasid al Shari'ah), but to impose them on 
the non-Muslims is an act quite the contrary to the true spirit of the Qur'an. (Al-Qur'an 42:15) Moreover, they strongly believe that Naik somehow overlooked the other aspect of the Shari'ah principle that states "the end does not justify the means". Besides that, his critics also claimed that Naik's disapproval of Muslims wishing non-Muslims during their religious festivities also clearly depicts that he is a 'Salafi'.

Another issue that has prompted his critics to accuse him as a 'Salafi' scholar for the answer Naik gave to the question on Sufism. His explanation to his critics did not satisfy them. They felt that he was condemning the Sufis and their followers as a whole. Furthermore, they claim he had rejected all esoteric experience of great Sufi spiritual leaders (Haqqani 2011). As to whether this accusation on Naik is true or false will be thoroughly dealt with by the researchers in the appraisal of this study. Naik has been criticized by his critics when he claimed that the battle of Karbala which took place in $680 \mathrm{AD}$ is a political one. In addition to that, they complain that Naik's opinion on this matter in a way absolves Yazid who was the caliph at that time of all of his inhuman and barbaric acts against the innocent, pious, noblest, righteous men and the dearest members of the Prophet's family associates, especially Sayyidina Hussein. What further aggravated the feelings of his Muslim critics was when Naik used the expression radiallah taala wa anhu when he mentioned the name of Yazid in a public speech (Musthafa 2014). Quite contrary to Naik, his critics see Yazid as one who is not a fair and just leader, but one who reflects as an anti-hero model in the history of the Muslims. To them, Yazid was not only responsible but was truly behind the killing of Sayyidina Hussein.

\section{Controversial Statement}

Naik's religious enthusiasm has led him into making a number of controversial and provocative statements. At many times, such statements have ruffled people living in multi-religious countries of the world, particularly in India. In many instances during public lectures, Naik made disparaging remarks on other religious books other than the Holy script of the Muslims. Whenever the opportunity prevails during public debate/ forum he would openly declare that those religious books are inauthentic and contain nothing else other than fallacious teachings. It is widely believed by many that the act of disparaging other people's religion can cause polarization and disharmony within a society that may disrupt the peaceful co-existence of a multi-religious society. There are Muslims who feel that Naik should not get entangled himself in controversies by belittling other people's religion, but rather focus on the beauty, tolerance and values preached by Islam (Schwartz 2015).

Moreover, there are claims that say, Naik called Muslim countries not to tolerate the building of places of worship other than mosques. His exact words on this issue are: "How can we allow building of churches or temples in an Islamic state when their religion is wrong and when their worshipping is wrong?" (Naik 2015). The other complain on Naik is that, he likes to harass his questioners during public lectures to accept Islam substituting their own faith. Such demeanor of Naik has caused animosity among non-Muslim not only against him but also on Islam and other Muslims. On the issue of women too, Naik made a few condescending remarks. According to media reports, he said that Muslim males have the right over their female slaves to the extent that they are permitted to have a sexual relation with them (Dehlvi 2016).

The alleged Naik's statements on suicide bombing also become a controversy when the media reported that he approved the act as a war tactic. Having said that, Naik also refused to accept that the $9 / 11$ attack were perpetrated by a Muslim terrorist organization helmed by Osama bin Laden. On the contrary, he believed the 9/11 attack was an inside job carried out by the Bush administration. His views on 9/11 became controversial through a widely watched You Tube video in 2007 (Naik 2007). In this video, Naik stated the following (Shihab 2016; Naik 2007): "If he (Osama bin Laden) is 
fighting the enemies of Islam, I am for him". If he is terrorizing the terrorist, if he is terrorizing America the terrorist, the biggest terrorist, I am with him".

\section{Unclear Methodology}

Muslims and Non-Muslims academics dispute on the objectivity of Naik's methodology. His literal interpretation of scriptural texts turns up to be a subject of criticism. The methodology is known as Sophism. It is an argument apparently correct in form but actually invalid for the argument aimed especially to deceive. Scholars are overwhelmed with Naik's talent for his ability to memorize many textual references from the Qur'an and other varied religious texts, he quotes copiously in his talks and that becomes an added value to his presentation. But on the other hand, they claim that Naik references from the Holy Scriptures are taken out of context, especially the Bible. It is alleged Naik's Bible interpretation are meant to fit his preconceived conclusions. As such, his methodology has been analogically described as an arrow shoot on a blank board which was later drawn a bull's eye around it (Shihab 2016).

Furthermore, Naik's debates and public forums which aim to spread the true message of Islam in front of large audience worldwide were understood adversely. His critics complain that his public lectures are filled with hate campaign against people of other religion. It is obvious to many of his faultfinders that his style of preaching is seen provocative in nature. One of his critics said the following comments on Naik's style of preaching by saying:

"Naik's presentation with a self-pretentious smugness, which was designed to address the demand of a harsh inner city youth, wrangling his pant around his knee. The critique also posed on his preference to use sectarian language, and on his illogical arguments and his radical approach in the beginning of his public lecture. Even the religious radicals who do sermons never begin their discourse by saying; "Here I'm going to start my indoctrination session to prove that my religion is better than yours. In the next few hours, I'll do my best to convince you of my idea and ultimately convert you to my religion" (Dinesh 2016).

\section{Obscure Name}

Naik has been given many obscure names such as "a mentor of terrorism", "a founder of criminal NGO" and "a provocateur televangelist". Media reports in a few countries had alleged that Naik to be a promoter of 'Salafi' brand of Islam. Besides that, his interpretation and explanation on the terms like 'Jihad' and terrorism were misunderstood and misrepresented by his opponents and the media. His many and varying explanations on the two to the media more often served as a controversy than anything that clarified their actual meanings. Moreover, such media reports eventually culminated in portraying him as one who approves or in favour of terrorism as a means of defending one's ideas and nation when threatened by outside forces. Naik vehemently denied such a malicious attack on him. Taking media reports seriously, India, the UK and a number of other countries around the globe have banned Naik's entry into their nations. Looking in the light of Western democracy and freedom of speech, it will be unfair and a gross injustice to ban Naik's entry into the United Kingdom based on mere suspicion without having any tangible evidence.

Back in his own country, the Indian counterterrorism agency which is known as the National Investigation Agency (NIA), filed a report against Naik and his Mumbai-based non-profit organization, Islamic Research Foundation (IRF). The Hindu Nationalist Government of India 
imposed a five-year ban on the IRF under the country's anti-terror laws. India's Enforcement Directorate, which investigates economic crimes, has accused the IRF of money-laundering and the educational trust run by Naik has been prohibited to receive fund from abroad. Furthermore, Naik's organization was accused for recruiting young freedom fighters in the southern state of Kerala to join ISIL (Islamic State of Iraq and the Levant) or ISIS in the Middle East. All this and many more of the accusations on him and his organization involved in terror activities were never ever truly justified by the Indian Government. Naik not only denied these charges but has criticized ISIL or ISIS, referring to it as the "anti-Islamic state". In refuting this allegation he released a video that conveyed the Islamic message that violence and killing of the innocents are un-Islamic acts. In that video too, Naik went to the extent of stating that killing an innocent person regardless he is a Muslim or non-Muslim is the second major sin in Islam (Khalid 2017).

Non-Muslim scholars claim that Naik through his power of rhetoric was able to play the mind game with his enchanted listeners, often selectively quoting (rather twisting) the lines from sacred scriptures, to impose the ultimate idea of religious supremacy in the audience's psyche and ultimately establish the reason for one should embrace the particular religion. It could be seen throughout his repetition of two claims; his speeches have always dealt with communal harmony, and his opposition towards terrorism. His speeches and his Question \&Answer sessions offer ample evidence on his insistence to enforce the idea of religious supremacy with his ability to recall and connect lines from Islam, Christian and Hindu scriptures. It is claimed that Naik's idea of imposing religious supremacy and twisting the scriptures to attest his point are seen as instigation towards religious hostility. This uncalled action on the part of Naik is to undermine the faith of others, which threatens religious harmony in a multi-religious society. For instance Naik was seen to wrongly quote from the Vedas, "Na Tasya Pratima Asti (There is no image for Him)" to mean Hindus scriptures contradicts the idea of idol worshipping and a 'Pratima' (similitude/idol) isn't God and it is inaccurate according to the report. He is seen as ignorant of the fact that Vedas also see God in everything, including in the 'Pratima'. The critique justifies that Naik's assertions that he is delivering the message of peace is not true (Dinesh 2016).

\section{Analysis and Appraisal}

It is an undeniable fact that Naik earned his reputation as a dai (preacher) through his Islamic propagation work. When Naik initiated his missionary work in 1991, he was seen unique on the Indian sub-continent. His uniqueness as dai was well demonstrated his braveness in voicing the grievances of the Muslim ummah and the truth of Islam. His mastery of the subject matter in comparative religion has given credential to him to be courageous and this has been admired by his fan group all around the world. Furthermore, he is seen by his admirers as a "hero" of Islam defending Islam and the Muslim Ummah. His fearlessness in speaking up his mind will be seen as a personality trait by his followers for many years to come. Besides that, his power of memory and ability to quote from different religious texts amazed many sundry and laity. Simplicity of his language during his public forum has drawn huge crowd and has made the audience to listen to him attentively. Far from being apologetic to other faith groups, he spoke forcefully by making cross reference to the difference scriptures. All this and more he did to prove the Quran as a Book of spirituality and science. He finds no major contradiction between the Quran and science. His exact words on this matter are:

We want to remove common misconceptions about Islam... We want to show that unlike other religions there is no contradiction between Islam and modern science. On the contrary, there is not a single verse of the Koran [that] opposes established 
scientific facts. It may conflict with certain theories of science, but none of these, like evolution, has been scientifically proved, and they change all the time ... Many of these facts were anticipated in the Koran. [The] Koran speaks, for instance, of Big bang already fourteen hundred years ago (Blom Hansem 2001).

His method of engaging his opponent in public forums seem convincing to his ardent followers among the Muslims. As a modern day preacher Naik uses technology in the most productive manner. To him, technology can work either ways: positive or negative. It can deliver the message of Islam in the fastest way to the people of the modern age. At the same time the media has a tendency to portray the negative as positive, black as white and a villain as a hero (Naik in Shihab's video presentation 2016). Understanding the power of the modern media has led him to establish his own 'Peace TV' that reaches millions of people around the globe. Feedbacks from his viewers have indicated to him that he has used media for a good course and not to create discords among people of different religion. Furthermore, Naik has been looked upon as an iconic figure in the Muslim world for his commitment in clarifying the many misconceptions on Islam posed by non-Muslims. Over and above, he is good at highlighting the major differences and similarities that exist among the popular religions of the world. His live appearance and over the media lectures have reached millions of people around the globe.

In spite of his fame and glory as a public figure, at times Naik turns out to be a controversial figure. This side of Naik can be clearly seen on the many videos posted on YouTube and other social media. What follows below here will an analysis on some of the controversies that linger around his personality. In many ways Naik's methods of dakwah (preaching) resemble that of his teacher and mentor the Great Ahmed Deedat. Mastery of the subject, prior preparation and self-confidence propels him to emerge victorious in many of his encounters with scholars from other faith groups. Despite his self-claimed professionalism in handling and entertaining questions at the end of debates, many non-Muslims find him to be unfair in giving equal opportunity. (Haron, 2014) His critics say, Naik likes to ridicule and make a mockery of their faith, scripture and catechism. To state a few of his provocative questions will be questions like; to which Christian denomination you belong to, are you circumcised, why do you eat pork, which bible do you read, is this teaching of your church or Jesus Christ, etc. Besides that, he also pesters his questioners by asking; why don't you become a Muslim now, will you be a Muslim if I answer your question, are you prepared to accept Muhammad (PBUH) as your prophet, etc. All this provocation and more from Naik was never seen by him as acts that do not go in tandem with the ways of the Prophet (PBUH).

Being under the tutelage of Ahmad Deedat has made Naik to imitate the way and mannerism of his "Guru". Deedat's militancy in oral communication can be well understood as he was living during the apartheid of the then South Africa. Deedat experienced verbal harassment from the missionary groups of his country as such he reacted the same way. Moreover, in South Africa it is a common norm for people to speak with a little bit of militancy. Deedat, in realizing the realities in his country were different from that of his students in their countries of origin, he usually gave the options in the methods of da'wah. There was a time; he even spoke to Naik by saying: "My son, there are two ways of fighting the battle, either with holy water or with fire and I have chosen to fight with fire. If you can fight with holy water you are most welcome, but I have chosen with fire' (Haron 2014). But in the case of Naik, he comes from India which is the largest democracy in the world. As a democratic and multi-religious country, in India people generally respect one another's religion and the masses are careful with the sensitivities when it comes to religious matters. As such, Naik's way of preaching should be more diplomatic and persuasive towards his audience and questioners. Quite the opposite to the preceding views, sympathizers towards Naik's missionary works in Islam claim 
that, people who oppose him should not deny in totality the fact that he experienced life during the time when India was under the supremacy of a secular government; a government at that time harboured ill feeling towards many minority communities, of which Islam is one. Later in his life, when Islam was seen as threat by the Indian secular government, Naik thought that it was his rightful duty as a preacher to defend the pristine teachings of Islam which is very far from the false accusations of the non-Muslims (Haron 2014).

Apart from the above arguments and counter arguments, when Naik's method of da'wah viewed in the light of the Prophetic traditions, it has become crystal clear that it is quite the contrary to the ways of the Prophet. During the time of the Prophet, he employed diplomacy, persuasion, tolerance, mutual-respect, etc. towards the adherents of other faith, particularly the Christians of Najran. Moreover, in his approach in propagating the religion he focused much on the similarities rather than on the differences that exist between Islam and other Abrahamic faith (Christianity and Judaism). The Quran on its part has set the precondition on how such debates/dialogues between Muslims and others can take place in a harmonious situation. The following verse is one example of a prerequisite under which a peaceful dialogue can take place:

Say:" O People of the Book! Come to common terms as between us and you: That we worship None but God; That we associate No partners with Him; That we erect not, From among ourselves, Lords and patrons other than God." If then they turn back, say ye:" Bear witness That we (at least) are Muslims (bowing to God's Will)." (Al-Quran $3: 64)$

Besides his dialogues with the People of the Book, the Prophet used to preach to the pagans of Mecca. Upon hearing him, there were some among them who used to dispute of what he preached. Under such circumstances, he had been advised to part ways with them in a peaceful manner or follow the ethical manner of agree to disagree. The Quran calls upon the Prophet to part ways with the non-Muslims in a peaceful manner (Al-Quran 109:1-6, 42:15)

However Naik on his part has defended that his style of preaching is in harmony with that of the Prophet of Islam. Naik further argued that his ways are not very far from what the Prophet (PBUH) has done during his time when faced with the challenges posed by the non-Muslim community of his time. In a similarly vein, when Naik's mentor Deedat was criticised, he too said that his method is none other than the Prophet's approach (Haron 2014). The researchers feel that Naik was no different from his mentor. In analysing Deedat's and Naik's approach one would discover that what was done by the two was none other than the norm of the day. Moreover, at the time Naik took the platform of Islamic da'wah, it was seen as an era whereby free speech and challenging debates were a common practice in many religious organizations; be they Islamic or others. In addition to that, intellectuals and religious leaders debated and contested ideas presented by their opponents. As such, to claim Naik was extreme in his approach is not a fair judgment (Haron 2014).

Another way of looking at Naik's passionate effort in winning converts to Islam is nothing more than a reciprocal act to the ways practiced by Christian missionary organizations worldwide that try to entice desperate and 'lost' souls of the Muslim community in war zone areas of the world by giving material and financial support. Unlike the Christian missionaries, Naik tries to win over hearts to Islam through sound reasoning and intellectual debate.

Taking a non-partisan stand, this research has thoroughly analyzed Naik's style of religious propagation. The findings of this research have indicated that though there are controversies that surround Naik as a preacher, he is still dear and pretty much liked by many in the Muslim world. His problems with the non-Muslims are mainly related to his way of communication and choice of words. 
The allegation that he is involved with terror organization has been proven not true by the US government and Interpol (Tikku 2017).

\section{Recommendation}

This research has objectively analyzed Naik as a personality, scholar, his style of preaching and most importantly the controversies that surround him. Upon weighing the pros and cons related to Naik, the researchers would like put forward the following recommendations:

1. In order to be more successful as a preacher, Naik has to employ diplomacy and persuasion. He has to be more lenient towards his questioners during public lectures.

2. Naik should avoid disgracing his questioners by asking provocation questions of their religions and practices in the midst of a vast Muslim audience.

3. He has to give equal opportunity for the questioners to articulate their ideas and not to intrude or make fun of them when they are seriously trying to explain their opinions.

4. Naik should not pester his non-Muslim questioners for a change of faith instantaneously at public forums. He has to respect their opinions and give ample time for them to ponder over his explanations, suggestions or invitations to embrace his religion.

5. He has to overcome his over-reactionary character, high pitch and his mentality of always wanting to win in a debate. What will be ideal for him to do is to present his case and leave it to the judgment of his audiences.

\section{References}

Al-Quran.

A Badaruddin, Mohammad Qayyum. 2016. Dr. Zakir Naik: Tidak Merbahaya Tetapi Membahagiakan. Selangor: Casamas Sdn. Bhd.

Ahmad, Rafiq \& Idrees, Haroon. 2015. The life and works of Ahmed Deedat: a Muslim scholar of Christian Bible. Al-Iddah 31: 159-179.

Blom Hansen, Thomas. 2001. Wages of Violence: Naming and Identity in Postcolonial Bombay. USA: Princeton University Press.

Dehlvi, Ghulam Rasool. 2016. How Zakir Naik Misinterpreted Islam for His Extremist and Misogynist Views. https://www.firstpost.com/india/how-zakir-naik-misinterpreted-islam-for-hisextremist-and-misogynist-views-2954568.html, Retrieved: 7th August 2018.

Dinesh, Unnikrishnan. 2016. Zakir Naik's biggest critics aren't Hindus, but his Muslim Neighbours. https://www.firstpost.com/india/zakir-naiks-biggest-critics-arent-hindus-but-his-muslimneighbours-2892906.html, Retrieved: 8th August 2018.

Dinesh, Unnikrishnan. 2016. Zakir Naik's IRF's alleged Islamic State connection makes a strong case for action against preacher. http://www.firstpost.com/india/zakir-naiks-irfs-allegedislamic-state-connection-makes-a-strong-case-for-action-against-preacher-2916108.html.

Retrieved: $11^{\text {th }}$ February 2018.

Esack, Farid. 2002. To Whom Shall We Give Access To Our Water Holes?. http://www.crosscurrents.org/Esack.htm, Retrieved: $8^{\text {th }}$ August 2018.

Haron, Muhammad. 2014. Ahmad Deedat: the making of a transnational religious figure. Journal for the Study of Religion 27(2): 66-93.

Haqqani, Shahnaz. 2011. Muslim Televangelist and the Construction of Religious Authority in the Modern World: The Case of Zakir Naik. USA: Emory University. 
Hidayathullah, Mohammad. 2001. New Recording by Yusuf Islam. http://www.islamicvoice.com/march.2001/news.htm. Retrieved: 8th August 2018.

BBC News. 2018. The influence of controversial preacher Zakir Naik. http://www.bbc.com/news/world-asia-india-38259592. Retrieved: 8th August 2018.

Catholic News Services. 2018. http://www.catholicnews.com/jpii/stories/story04.htm. Retrieved on the $23^{\text {rd }}$ January 2018.

Good Reads. 2018. Books by Islam. https://www.goodreads.com/author/list/209833.Yusuf_Islam. Retrieved: 8 $^{\text {th }}$ August 2018.

Good Reads. 2018. Books by https://www.goodreads.com/author/list/7133146.Zakir_Naik. Retrieved: 31 $1^{\text {st } J u l y, ~} 2018$.

Khalid, Saif. 2017. Zakir Naik: Why India wants to arrest the preacher. https://www.aljazeera.com/indepth/features/2017/05/india-arrest-preacher-zakir-naik170521055023564.html. Retrieved: $8^{\text {th }}$ August 2018.

King Faisal Prize. 2015. Dr. Zakir A. Naik. http://kingfaisalprize.org/dr-zakir-a-naik-2/, Retrieved: 31 st July, 2018.

Ladika, Awaluddin Ryrito. 2018. The Analysis of Figurative Language Used by Dr. Zakir Naik. Indonesia: Jambi University.

Musthafa, Jasbeer. 2014. Mediation and Muhammad's message: characteristics of online Islamic Evangelism consumed by Indian youth. Malaysian Journal of Media Studies 16(1): 13-24.

Naik, Zakir. 2007. Most Common Questions: Asked on Concept of God in Christianity. Kuala Lumpur: Saba Islamic Media Sdn. Bhd.

Naik, Zakir. 2007. 10 Most Common Questions: Asked by Hindus about Islam. Kuala Lumpur: Saba Islamic Media Sdn. Bhd.

Naik, Zakir. 2015. 20 Most Common Questions: Asked By Non-Muslims. Kuala Lumpur: Saba Islamic Media Sdn. Bhd.

Naik, Zakir. 2015. Temples are not allowed in UAE \& other Islamic nations. https://www.youtube.com/watch?v=L-QkUXThkkM, Retrieved: 8th August 2018.

Sadouni, Samadia. 2013. Ahmad Deedat, internationalisation, and transformation of Islamic polemic. Journal of Religions in Africa 43(1): 53-73.

Schirrmacher, Christine. 1997. The influence of German Biblical criticism on Muslim apologetics in the 19 th century. Contra Mundum.

https://www.contra-mundum.org/schirrmacher/rationalism.html, Retrieved: $8^{\text {th }}$ August 2018.

Schwartz, Stephen. 2015. Zakir Naik, Radical Islamist Video Evangelist. https://www.huffingtonpost.com/stephen-schwartz/zakir-naik-radicalislami_b_6945990.html, Retrieved: 7th August, 2018.

Shihab, Rayhan Mahmud. 2016. What are your thoughts about Zakir Naik allegedly inspiring/influencing Dhaka terror attacks of 2016?. https://www.quora.com/What-areyour-thoughts-about-Zakir-Naik-allegedly-inspiring-influencing-Dhaka-terror-attacks-of2016, Retrieved: 7th August 2018.

Swami, Praveen. 2011. Roads to perdition? the politics and practice of Islamist terrorism in India in Warikoo, Kulbhushan. In, Religion and Security In South And Central Asia. (pp. 52-66). London: Routledge.

Tikku, Aloke. 2017. "Premature": Interpol Snubs India On Red Corner Notice For Zakir Naik. https://www.ndtv.com/india-news/premature-interpol-snubs-india-on-red-corner-noticefor-zakir-naik-1788665. Retrieved: 7th August, 2018. 